\title{
Interaction and links of technologies life cycle and life cycle of innovations of an industrial enterprise
}

\author{
Irina Mayorova* \\ Department of Navigation and \\ management a ship \\ Azov maritime institute National \\ university «Odessa maritime \\ academy» \\ Mariupol, Ukraine \\ https://orcid.org/0000-5703-4338-4675
}

\author{
Svitlana Bessonova \\ Accounting and Audit Department \\ Pryazovskyi state technical university \\ Mariupol, Ukraine \\ https://orcid.org/0000-0003-4938-3375
}

\author{
Oleg Klenin \\ Accounting and Audit Department \\ Pryazovskyi state technical university \\ Mariupol, Ukraine \\ http://orcid.org/0000-0003-3146-4847
}

\begin{abstract}
The paper analyzes efficient development of innovative activities can be carried out, on the basis of conducted research, on research base, the foundations of which are laid upon the objective analysis of the existing and anticipated results of the processes of developing and implementing of innovations. To realize it in our work a series of common scientific, special and applied investigation methods was used. It has been proved that for an industrial enterprise life cycle of innovative technologies and life cycle of innovative product are closely interconnected in time and execution. It has been proposed a complex of indices that give an opportunity to make an objective analysis of the current state of things and capabilities of an industrial enterprise, regarding designing and manufacturing an innovative product.
\end{abstract}

Keywords- life cycle of innovations, technologies, interaction, manufacture, stages, indices, personnel, industrial

I. STATEMENT OF THE PROBLEM IN GENERAL WAY AND ITS RELATION TO IMPORTANT SCIENTIFIC OR PRACTICAL TASKS

It is the high rate of innovative processes that seems to be a typical feature of nowadays life: in a wider sense it means the rate of business alternations, dynamics of changes in the way of life of consumers and their demands, expectations and tastes. There are no "eternal" technologies in life. As time goes by the existing technologies are replaced with new ones, more adapted to the contemporary life conditions and demands of the society. There can't be "eternal" innovations. Each innovation has its own life cycle, its origin and its ending. Innovations into products are the most important innovations type for an industrial manufacturer, but they also have stages of their life cycle. An ability to use influence and modify life cycles of innovations brings can give a clear idea of the existing characteristics of innovative capabilities of an industrial manufacturer, capabilities of the branch it belongs to and the entire country. The wealthiest countries of the world consider innovations to be of paramount importance for development of their economies and they are their top priorities.

\section{ANALYSIS OF RECENT STUDIES AND PUBLICATIONS THAT HAVE INITIATED PROBLEM SOLUTION, WHICH THE AUTHOR REFERS ON}

In nowadays world innovations development, their support and mechanisms of their implementation are top priorities of national economies of all countries of the world. So in the article [1] with addressing to the sources [2-3] an accent is made on the idea that the basis of the national safety of such mighty country like the USA is its leadership in science and engineering and innovations are but a tool with which the country solves quite a wide spectrum of own problems in safety, energy saving, health care and protection, ecology, economy etc. An example of such highly developed country like Japan shows the country's interest and actual directions for implementation of innovations, particularly:" Japan links its future with innovations, laying them into the foundation of five key directions of the country's development: lasting and healthy life; safe and reliable society; diversification of the ways of activities and employment; solution of the global ecological problems; provision of the openness of the society", as the group of the authors of the article [1] state with reference to the source [4].

The European Commission in documents [5-6] often describes innovations as new sources of economic growth, transition of the world economy to a new, higher quality level “... of powerful, all-embracing and steady development [6] is to be made through implementation of innovations".

\section{Highlighting UNRESOLVED ISSUES TO WHICH THE ARTICLE IS DEVOTED}

Great many legislative and regulating documents, like The law of Ukraine "On innovative activities"[9], "On the strategy of steady development of Ukraine-"Ukraine--2030 [10];"On priority directions of innovative activities in Ukraine [11]; "The concept of engineering, scientific and innovative development of Ukraine [12]; "The strategy of innovative development of Ukraine for the years of 20102030 under conditions of global challenges [13]; The law of Ukraine "On science and engineering activities [14]; "On endorsement of the Concept of development of the national system of innovations [15]; "On establishing the innovative 
structure in Ukraine: the special-purpose state economic program for the years of 2009-2013 [16] and many others provide the necessity of transition of the national economy to innovative character. For the time being the country does not have a Strategy of innovative development of its own, neither it has guiding lines, directions and indices of development of the national innovative economy. Such situation seems to be quite awful for the country, as it could mean, first, time losses for creation of the required knowledge for the national economy and, second, the national economy can seriously lag behind the dynamics of the world innovative development and, third, continuation of application of obsolete facilities and technologies and incompatibility of the technological structure of Ukrainian enterprises with their foreign competitors and possibly potential (theoretical) consumers. Such situation is partially connected with the fact that each technology, just like innovation has a term of its own life cycle, which is temporary and cannot last eternally, sometimes its life can be quite short.

\section{ARTICLE OBJECTIVES}

To undertake theoretical and practical studies of intercommunication and interdependence of life cycle of innovative technologies and innovative product.

\section{THE MAIN MATERIAL OF THE RESEARCH WITH JUSTIFICATION OF FINDINGS}

The model of product's life cycle has been specified in numerous research works of both theoretical and practical orientation. According to those regulations first stages of development of a product are always not steady and are difficult to modify. It is worthwhile mentioning here that $\mathrm{M}$. Porter in [18] and O.V. Savchuk in [19] stated that innovations in a product is a prevailing type of innovations. Innovations for a product have an objective of improving its exploitation characteristics and its objective may not always be reduction of production costs. Should any innovative product prove to be a success, retaining optimal characteristics and configurations, it may look like an product-example for the market. When the process layout of the product becomes understandable in its stages and steps and stable in expenses, the production processes become automatic and here innovations in production process become dominant in their character, acquiring the character of manufacturing innovations, aimed at reduction of production costs. After a while both product and manufacturing innovations begin to decelerate.

Such character of development of innovations is not typical for all branches of industry. According to the research [18] in the branches, where the final product is not differentiated, like, for example, coal and mineral extracting industry and some products of chemical industry there is no consecutive appearance of a series innovative products in the market, that can lead to an ultimate ready products, or it may happen quite swiftly, like, for example, in chemical industry. In such branches of industry, like civil and military aircraft construction, construction of large turbogenerators, innovative design does not reach the stage of automatic mass production and the bulk of innovations is aimed directly at the products. M.Porter defines later:" The diagram of technological evolution develops depending upon the branch characteristics and is to be interpreted and understood within the general concept of evolution of the branch's structure. An innovation is simultaneously an answer to the stimuli, formed by general structure of the enterprise and a powerful influence upon these structures" [18].

Technological evolution and the life cycle of an innovative product interact according to the diagram, pictured in Figure 1. Once an innovative product appears in the market, which becomes quite successful and acceptable for the consumers and the scope of enterprise's activities widens, the quantity of new products also grows and innovative technologies become quite meaningful. Eventually the enterprise starts to realize what the product's structure should be and how the activity for creation of value should be organized. Alternations in the technological process starts to be made after that [18].

Eventually enterprises become more familiar with the consumers' needs and commence to copy inventions from one another, it leading to the process of product's standardization. Further technological development reaches a certain limit, after which it becomes quite problematic to perform further perfection of the product, as it can be quite costly and may not be repaid at realization of goods in the consumption markets [18].

M. Porter proved in [18] that innovative technologies that are used for product's manufacturing and innovative technologies of the manufacturing process are mutually connected. Production -and technological innovations improve the processes of manufacturing of products. The following innovations are considered to belong to this type: transition to newer more advanced types of raw materials, fuel, application of new types of machine-tools, appliances, tools and automation means, that are more precise, less energy and resources consuming, low wasted or wastes free, application of most up-to-date or advanced technologies and technological processes.

Product's innovations possess a complex character according to their influence upon the general result. Their realization at the stages of the life cycle of innovations (see Fig.1) has a beneficial influence upon further design and implementation of all innovations of industrial manufacturing. Lots of practical and experimental examples show that development of product's innovations, especially if they deal with implementation of the most up-to-date computer systems of automatic design of products, appliances actually represent innovations in the domain of manufacturer's research and design activities. Their manufacturing demands implementation of new types of technologies, raw and other materials at the enterprise, i.e. complete implementation of manufacturing and technological innovations. [19]

Application of new types of raw and other materials, energy sources and equipment in manufacturing process may lead to a necessity to address to new resources markets and implementation of new types of work in them. 
Realization of product's innovations may lead to a necessity of finding new consumption markets and mastering new methods and types of working with consumers, i.e. activation of implementation of innovations in sales activity.

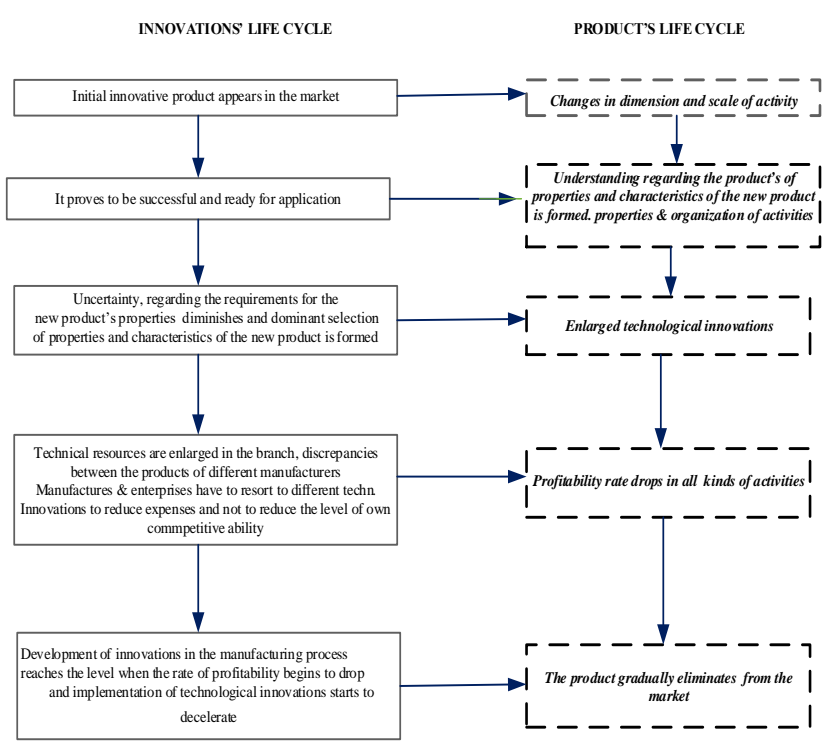

Fig. 1. The diagram of interaction between innovations and the life cycle of an innovative product. The diagram was compiled by the authors, according to the source [18].

Preparation and sale of product's innovations may be connected with a necessity of implementing innovations into the methods and approaches in internal production and organization processes and management, particularly a need of finding new approaches to evaluation of results of personnel's work, forms of labour payment or setting up new subdivisions of the enterprise. As an example of such innovations we may mention innovations, caused by the need of monitoring and correcting the processes of manufacturing and realization of products, especially at the initial stage of their life cycle.

O.V. Savchuk showed in his monograph [19] that a complex analysis of the state and opportunities of manufacturer's innovative activities had to be made in two mutual perspectives. The first one - some innovative peculiarities of the main layout of its functioning, i.e. manufacturing and the processes of design and manufacturing of ready products. The other one peculiarities of realization of the main stages of innovations life cycle (ILC, hereinafter) in the process of manufacturer's innovative activities, the most important ones being research and production [19]. Hence, the objects of manufacturer's complex analysis, from the point of view of opportunity of reproducing and state of innovative activity are: manufacturer's production, the processes of its design and manufacturing, i.e. the manufacturer itself, while the object of investigation could be innovative peculiarities of the above-mentioned components and details of realization of their sales in the process of functioning of the main ILC phases.
For innovative characteristics of objects it is necessary to perform concretization of their innovative capabilities and propose the corresponding indices that can measure them. O.V. Savchuk in his monograph [19] singled out the following economic categories for innovative analysis of a manufacturer: manufacturer's innovative potential, the degree of application of the manufacturer's innovative potential, the degree of application of innovative level of the manufacturer, production innovative level, and innovative level of the manufactured products. Innovative level of manufactured products is the main index of manufacturer's innovative activity. Such situation may be explained by the fact that innovative level of products reflects the actual result of implementation of the main stages of ILC, as well as the efficiency of functioning of all elements of an industrial manufacturer, with an exception of its sales functions.

For some production types the process of design of new, or improved existing product may theoretically represented with three organization approaches. The first is when the manufacturer possesses some opportunities and develops innovations individually, simultaneously acquiring the accompanying documentation and legal rights for manufacturing of new products from other organizations, that perform designing or research work. The second and the third approaches can happen when the manufacturer carries out only one type of innovative work or designs new products individually, preparing its improved variant, or acquires the rights and corresponding documentation for its manufacturing from other designers, thus performing the socalled outsourcing of innovative activity. Two types of resources may be used for the above-mentioned three types of organization approaches: at designing or improving the products, also at information search for acquisition of the documents for the right to manufacture innovations from other designers; at realization of the manufacturing stage of ICL. In general it should be mentioned here that of all stages of ILC, realized by a manufacturer, the production stage of ILC is the typical stage for a manufacturer. This is the principal peculiarity of innovative activity of domestic manufacturers, manufactures from CIS countries, while foreign manufacturers reveal quite a different approach to organization of innovative activities. S.Youriy and E. Savelyiev in their monograph [20] show the difference in approaches to evaluation of readiness of an innovative product for consumption, applied by native and foreign businessmen." There are some principal differences in the thoughts of native and foreign designers and manufacturers, regarding technology as goods.

The main resource approaches to realization of production and research stages of ILC are shown in Fig.2. The main resources, that a manufacturing enterprise uses in the process of realization of the production stage of ILC are its own technical, labour and material resources. Material resources are not stable and largely depend upon alternations in prices and market conjecture as compared to technical and labour resources. 


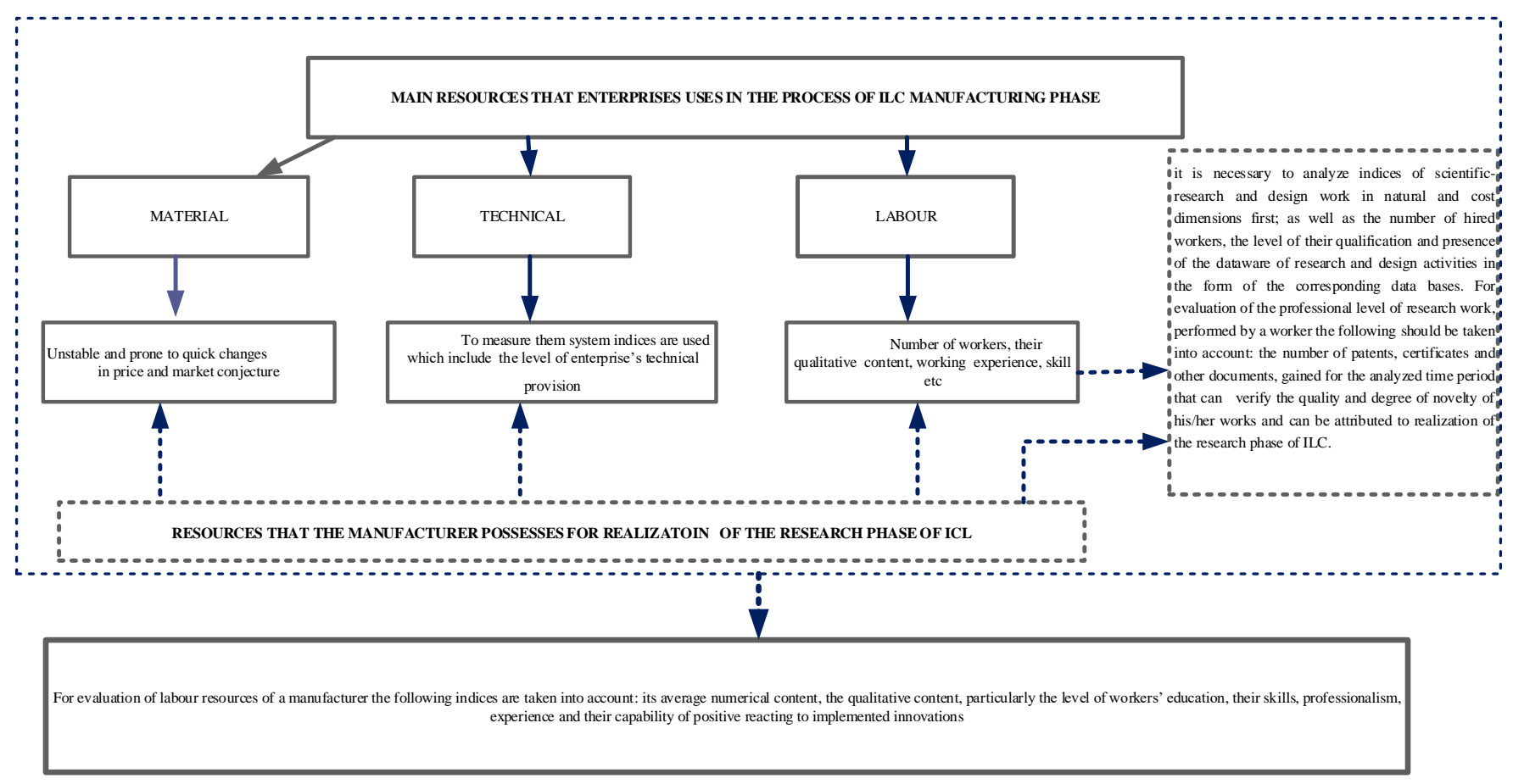

Fig. 2. The main resource approaches to realization of research and manufacturing stages of ICL (developed by the author, in accordance with the sources $[19,21])$

An enterprise buys material resources. So, it cannot influence them, it only can replace its old material resources with new and advanced ones or change the markets of purchase and suppliers. Hence, technological and labour resources are most important potential resources for investigation and reproduction of manufacturing activity. For measuring of technical resources a system of indices is used, that includes: technical equipment, available for manufacturing, technical and economic level of the existing machines and equipment, the level of technological processes and the level of application of production facilities.

For evaluation of labour resources of a manufacturer the following indices are taken into account: its average numerical content, the qualitative content, particularly the level of workers' education, their skills, professionalism, experience and their capability of positive reacting to implemented innovations. A.V. Doubinina in [21] expressed a similar ideas regarding efficient implementation of innovations into personnel management of an industrial enterprise. She, also, connects efficient implementation of innovations into management of personnel with the main objectives of an enterprise: “ ...increase in enterprise's profitability. Improvement of labour production, ensuring efficient learning and development of personnel, improvement of life quality, improvement of social and psychological climate of the staff and stimulation of innovations and adaptation of personnel to such innovations" [21]. ]. As a next step A.V. Doubinina shows the groups into which personnel technologies can be united: "All personnel technologies can be united into the following groups: personnel technologies of the staff in charge of loans; selecting and recruiting personnel technology; personnel technology of raising operating efficiency; personnel technology of control of the staff and IT personnel technology" [21]. It is worthwhile mentioning here that these technologies make it possible to carry out such principles of personnel management like efficiency and promptness of reacting to changes [21]. Such approach is considered to be required for the control over the processes of innovations' life cycle of an industrial enterprise with all its properties and habits. For the analysis of the resources, that the manufacturer possesses for realization of the research stage of ICL (see Fig.2) it is necessary to analyze indices of scientific-research and design work in natural and cost dimensions first; as well as the number of hired workers, the level of their qualification and presence of the data ware of research and design activities in the form of the corresponding data bases. For evaluation of the professional level of research work, performed by a worker the following should be taken into account: the number of patents, certificates and other documents, gained for the analyzed time period that can verify the quality and degree of novelty of his/her works and can be attributed to realization of the research phase of ILC.

Technical and labour resources of a manufacturing enterprise and the resources it applies for realization of research and investigating work and designing determine an opportunity of realization of research and manufacturing ICL phases and in technical literature are considered to be resources, characterizing latent potential capabilities of an industrial manufacturer for its realization of innovative activities, i.e. those, reproducing its innovative potential.

According to the data of National report [7, 8] so far the national share of realized innovative production does not 
exceed $2 \%$ of the total output, the share of industrial enterprises involved in innovative activities is just $15 \%$.

"Prevailing in the domestic structure are raw materials products of the third and the fourth technological type, they largely depend on conjuncture cycles in the world markets and their share is $58 \%$ and $38 \%$ respectively. Only $4 \%$ of the output belongs to the fifth technological type, while production of the goods, belonging to the sixth technological type is practically missing $(0,1 \%)$ " [8].

The National report [8] pays a special attention to the general and separate problems of insufficient implementation at the national industrial enterprises, stating that "... the high degree of wear of the main production means, obsolete technological processes and business models, ultrahigh energy and resource consumption production, badly developed infrastructure, especially application of data and communicative platforms within the chains of creating added value to the products" [8].

In [1] publication the group of authors warns with a reference to the source [22] about backwardness of the Ukrainian innovative market in comparison with the world market:" The contemporary state of the world economy is characterized by large-scale transformations, that are revealed in development of key technologies of 4.04 Industry, smart-specialization, growth in intensity of international competition and acceleration of all processes that are getting global and more open". According to evaluations by the World economic forum 12 key technologies of the fourth industrial revolution are to form future social and economic medium: 1.-Artificial intellect and robotics; 2. Long-distance communication network points; 3. Virtual and extended realities; 4. Production of additives; 5.Blockchain and distributed accounting technologies; 6.New advanced materials and nanomaterials; 7. Accumulation, conservation and transmission of energy; 8. New computer technologies; 9. Biotechnologies; 10. Geoengineering; 11. Neurotechnology; 12.Space technologies.

Contemporary concept regarding the structure of industrial economy of the entire world lies in transformation of its separate segments into uniform ones and their integration into a global industrial complex :"...which is capable of highly profitable activity and self-development, uniting systematically structured branch divisions, is balanced with demands of external and internal markets and corresponds to the requirements of ecologically safe development and efficient application of energy and resources [1].

\section{CONCLUSIONS}

With due regard to the existing points of view of scholars and the authors own investigations the interaction between the life cycles of innovations and life cycles of innovative product was expanded, namely: growth in the scale of enterprise's activities aimed at implementation of innovations, perfection of manufactured products and understanding of organization of the manufacturing process, standardization of innovative product, extension of innovative technologies, reduction of profits, gained from technological innovations and canceling of their implementation. For an industrial enterprise the research work phase and phases of implementation and production are of paramount importance. For the objects of manufacturer's complex analysis from the positions of capabilities of reproducing and the state of innovative activity we may mention: the products, that are manufactured by the manufacturer, the processes of their designing and developing, the manufacturer itself, while the subjects of investigations could be innovative peculiarities of the afore-mentioned components and peculiarities of their sale in the process of functioning of all main phases of innovations' life cycle.

Innovative level of production is the main index of manufacturer's innovative activities as at reflects the actual efficiency of reproduction of the main phases of innovations' life cycle and effectiveness of functioning of all elements of an industrial manufacturer, excluding its sales functions.

The importance of innovative process has considerably grown throughout the entire world and the situation in the national industry is not an exception. Efficient development of innovative activities can be carried out, on the basis of conducted research, on research base, the foundations of which are laid upon the objective analysis of the existing and anticipated results of the processes of developing and implementing of innovations.

The results of our investigation have shown that for an industrial enterprise life cycle of innovative technologies and life cycle of innovative product are closely interconnected in time and execution. For any industrial enterprise research and production are the main phases of the life cycle of both product and technologies. Special attention is paid to personnel of industrial enterprise, its skills and qualification, as they give an opportunity to carry out research, obtain the results, design an innovative product and manufacture it.

Innovative level of production is the most important indicator of innovative activities of an enterprise. Effectiveness of reproduction of the main phases of the life cycle of industrial innovations and efficiency of functioning of all components of an industrial manufacturer can be realized only through innovative level of production.

Ability to use, to influence and regulate the life cycles of innovations gives imagination about present descriptions of innovative possibilities of industrial producer, possibilities of industry to which he belongs and countries in general. The richest countries of the world were taken away by innovations to the main task and main priorities of development of their economies.

Research of interconnection of life cycle of innovative technologies and life cycle of innovative product rotined not effectiveness of picture of innovations, as a successive change of the stages: knowledge - research - developments - innovative products - market - money - new knowledges. Contemporaneity changes traditional approach on the picture of innovations, as. Efficiency of innovative 
process is considerably stipulated intensity of simultaneous connections, communications and co-operation of all participants of this process. Inability to co-operation brakes the process of innovative development and reduces production potential of industrial enterprise.

\section{REFERENCES}

[1] Do pytannja pro strateghiju innovacijnogho rozvytku Ukrajiny abo jakoju maje buty strateghija innovacijnogho rozvytku Ukrajiny / V.P. Vyshnevsjkyj, I.Ju. Jeghorov, V.I. Ljashenko, V.P. Antonjuk, S.I Knjazjev, I.Ju. Pidorycheva, L.I. Kovchugha // Visnyk ekonomichnoji nauky Ukrajiny, №2 (35), $2018 . \quad$ URL: http://dspace.nbuv.gov.ua/handle/123456789/150576: [in Ukrainian].

[2] National Security Strategy of the United States of America. The White House. Washington DC. December 2017. URL: https://www.whitehouse.gov/wp-content/uploads/ 2017 /12/NSSFinal-12-18-2017-0905.pdf.

[3] A Strategy For American Innovation. National Economic Council and Office of Science and Technology Policy. The White House. Washington DC. October 2015. URL: https://obamawhitehouse.archives.gov/sites/default/files/strategy_for _american_innovation_october_2015.pdf

[4] Innovation 25. Creating the Future, Challenging Unlimited Possibilities. Executive Summary. February 2007. URL: http://japan.kantei.go.jp/innovation/interimbody_e.html

[5] Innovation. European Commission. 2018. URL: https://ec.europa.eu/ growth/industry/innovation_en.

[6] OECD Innovation Strategy 2015. An Agenda for Policy Action. OECD. Paris. June 2015. URL: https: //www.oecd.org/sti/OECDInnovation-Strategy-2015-CMIN2015-7.pdf.

[7] Cili stalogho rozvytku 2016-2030. Predstavnyctvo OON v Ukrajini. URL: http://www.un.org.ua/ua/tsili-rozvytku-tysiacholittia/tsilistaloho-rozvytku. [in Ukrainian].

[8] Cili stalogho rozvytku. Nacionaljna dopovidj 2017. URL: http://un.org.ua/images/SDGs_National ReportUA_Web_1.pdf [in Ukrainian].

[9] Pro innovacijnu dijaljnistj: Zakon Ukrajiny vid 16.10.2012 . № 5460VI / Verkhovna Rada Ukrajiny. URL: https://zakon.rada.gov.ua/laws/show/40-15. [in Ukrainian].

[10] Pro Strateghiju stalogho rozvytku «Ukrajina-2030»: Proekt zakonu Ukrajiny vid 07.02.2019 № 2679-VIII / Verkhovna Rada Ukrajiny.
URL: https://www.undp.org/content/dam/ukraine/docs/SD\%203-21.pdf . [in Ukrainian]

[11] Pro priorytetni naprjamy innovacijnoji dijaljnosti v Ukrajini: Zakon Ukrajiny vid 16.10.2012 № 5460-VI / Verkhovna Rada Ukrajiny. URL: https://zakon.rada.gov.ua/laws/show/3715-17. [in Ukrainian].

[12] Koncepcija naukovo-tekhnologhichnogho ta innovacijnogho rozvytku Ukrajiny: Postanova Verkhovnoji Rady Ukrajiny vid 13 lypnja 1999 № 916-XIV / Verkhovna Rada Ukrajiny. URL: https://zakon.rada.gov.ua/laws/show/916-14 [in Ukrainian].

[13] Strateghija innovacijnogho rozvytku Ukrajiny na 2010-2030 roky v umovakh ghlobalizacijnykh vyklykiv. Postanova Verkhovnoji Rady Ukrajiny vid 21 zhovtnja 2010 roku № 2632-VI URL: https://zakon.rada.gov.ua/laws/show/2632-17 [in Ukrainian].

[14] Pro naukovu i naukovo-tekhnichnu dijaljnistj: Zakon Ukrajiny vid 26.11.2015 N 848-VIII. URL: https://zakon.rada.gov.ua/laws/show/848-19 [in Ukrainian].

[15] Pro skhvalennja Koncepciji rozvytku nacionaljnoji innovacijnoji systemy: Rozporjadzhennja Kabinetu Ministriv Ukrajiny vid 17 chervnja 2009 r. № 680-r / Kabinet Ministriv Ukrajiny. URL: https://zakon.rada.gov.ua/laws/show/680-2009-\%\%80. [in Ukrainian].

[16] Stvorennja v Ukrajini innovacijnoji infrastruktury: derzhavna ciljova ekonomichna proghrama na 2009-2013 roky: Postanova Kabinetu Ministriv Ukrajiny vid 14 travnja 2008 r. № 447 / Kabinet Ministriv Ukrajiny. URL: https://zakon.rada.gov.ua/laws/show/447-2008$\%$ D0\%BF. [in Ukrainian].

[17] Pro vnesennja zmin do Zakonu Ukrajiny «Pro innovacijnu dijaljnistj». Pojasnjuvaljna zapyska Kabinetu Ministriv Ukrajiny vid 26.03.08. № 534. / Kabinet Ministriv Ukrajiny. URL: http://ndipzir.org.ua/wpD1\%8C.pdf. [in Ukrainian].

[18] Porter M. Konkurentnoe preimushchestvo: Kak dostich' vysokogo rezul'tata i obespechit' ego ustoychivost'/ Michael Porter; Per. s ang., 2-e izd., M.: Al'pina Business Books, 715 p., 2006.

[19] Savchuk A.V. «Teoreticheskie osnovy analiza innovatsionnykh protsessov v promyshlennosti»: monografiya / NAN Ukrainy. In-t ekonomiki promyshlennosti, Donetsk, 448 p., 2003. [in Ukrainian].

[20] Ekonomichni problemy XXI stolittja: mizhnarodnyj ta ukrajinsjkyj vymiry / Za red. S.I. Jurija, Je.V. Saveljjeva, 595 p., 2007 [in Ukrainian].

[21] Dubinina Ja.P. Osnovy kadrovogho menedzhmentu. URL: http://semestr.com.ua/book_102.html. [in Ukrainian].

[22] Readiness for the Future of Production Report 2018. URL: https://www3.weforum.org/docs/ FOP_Readiness_Report_2018.pdf 